\title{
Penerapan Status Pengguna Pada Tindak Pidana Narkotika Dalam Prespektif Undang-Undang Nomor 35 Tahun 2009 Tentang Narkotika
}

\author{
Montana Maruli Pakpahan', Erwin Owan Hermansyah², Lukman Hakim³ \\ ${ }^{123}$ Fakultas Hukum, Universitas Bhayangkara Jakarta Raya, Direktur Eksekutif Lemkapi \\ Email: oneway8686@gmail.com
}

Received : 17 Ags 2021 | Revised : 16 Sep 2021| Accepted : 30 Sep 2021 | Published : 9 Dec 2021

\begin{abstract}
The aim of the author examines the application of imprisonment for a narcotics user and optimizes the provision of rehabilitation rights for narcotics users from the perspective of Law Number 35 of 2009 concerning Narcotics, is to describe the extent to which sentences for narcotics users are applied and what penalties are in accordance with statutory regulations in Indonesia and how to optimize the provision of rehabilitation rights for narcotics users in Indonesia and what are the obstacles in granting rehabilitation rights. This type of research is a normative juridical legal research with descriptive characteristics derived from primary law and secondary legal materials. Secondary data includes primary legal materials, secondary legal materials and tertiary materials collected by means of literature studies. The data is compiled in the form of a description and then analyzed qualitatively, meaning that the data is interpreted and discussed based on theories (doctrines) and the principles and legal regulations relating to the subject matter. The implementation of prison terms for a user is not sufficiently in accordance with the perspective of Law Number 35 of 2009 concerning Narcotics because Law Number 35 of 2009 concerning Narcotics regulates the right to rehabilitation for narcotics users, namely placing narcotics abusers / users into rehabilitation institutions through a judge's decision. because this is a very good alternative to the provision of criminal sanctions in terms of deferent aspect and refresh aspect. However, the implementation of rehabilitation rights for narcotics users in Indonesia has not been optimal due to several obstacles, both from internal, external and legal regulations, which make narcotics users often given imprisonment penalties rather than rehabilitation crimes.
\end{abstract}

Keywords: Narcotics Abuse, Users, Rehabilitation

\begin{abstract}
ABSTRAK
Tujuan penulis meneliti mengenai penerapan hukuman penjara bagi seorang pengguna narkotika dan optimalisasi pemberian hak rehabilitasi bagi pengguna narkotika prespektif Undang-Undang Nomor 35 Tahun 2009 tentang Narkotika, adalah untuk mendeskripsikan sejauh mana hukuman bagi pengguna narkotika diterapkan dan hukuman apa yang sesuai dengan peraturan perundang - undangan di Indonesia serta bagaimana upaya optimalisasi pemberian hak rehabilitasi bagi pengguna narkotika di Indonesia dan apa kendala - kendala dalam pemberian hak rehabilitasi tersebut. Jenis penelitian ini adalah penelitian hukum yuridis normatif dengan karakteristik deskriptif yang bersumber pada bahn hukum primer dan bahan hukum sekunder. Data sekunder mencakup bahan hukum primer, bahan hukum sekunder dan bahan tertier yang dikumpulkan dengan cara studi pustaka. Data disusun dalam bentuk uraian
\end{abstract}


kemudian dianalisis secara kualitatif, artinya data ditafsirkan dan didiskusikan berdasarkan teori-teori (doktrin) dan asas-asas serta peraturan hukum yang berkaitan dengan pokok permasalahan. Penerapan hukuman penjara bagi seorang pengguna belum cukup sesuai dengan prespektif Undang-Undang Nomor 35 Tahun 2009 tentang Narkotika karena UndangUndang Nomor 35 Tahun 2009 tentang Narkotika mengatur mengenai hak rehabilitasi bagi pengguna narkotika yaitu menempatkan penyalahguna/pengguna narkotika ke dalam lembaga rehabilitasi melalui putusan hakim sebab hal ini adalah alternatif pemberian sanksi pidana yang sangat baik dalam rangka deferent aspect dan refomaive aspect. Akan tetapi penerapan hak rehabilitasi terhadap pengguna narkotika di Indonesia belum optimal dikarenakan terdapat beberapa kendala baik dari segi internal, eksternal dan regulasi hukum, yang membuat pengguna narkotika masih sering diberikan sanksi pidana penjara daripada pidana rehabilitasi.

Kata Kunci: Penyalahgunaan Narkotika, Pengguna, Rehabilitasi

\section{PENDAHULUAN}

Indonesia adalah Negara yang berkembang, dari segi ekonomi, pendidikan, dan perdagangan bebas. Hal ini sejalan dengan adanya kemajuan dalam berbagai bidang perkembangan suatu masyarakat dalam segala bidang menimbulkan poerkembangan peraturan hukum. Perkembangan dan pertumbuhan peraturan hukum tidak dapat dicegah karena masyarakat berharap dengan bertambahnya peraturan tersebut, kehidupan dan keamanan menjadi lebih baik karena bidang-bidang baru yang semula belum ada aturan hukumnya menjadi ada aturan hukumnya selain itu pada hal yang sudah ada aturan hukum sebelumnya dapat dilengkapi karena semakin kompleksnya kegiatan masyarakat yang harus diatur. Perkembangan dari peraturan hukum sudah pasti berdampak pada mungkin lahirnya jumlah pelanggaran baru terhadap baru tersebut. Keadilan terhadap anak yang berhadapan dengan hukum yaitu dengan dipastikannya semua anak memperoleh layanan dan perlindungan yang optimal melalui sistem peradilan. Targetnya adalah norma-norma, prinsip, dan standar hak anak yang secara penuh diberikan kepada setiap anak tanpa terkecuali, baik anak yang berhadapan dengan hukum atau anak yang berkonflik dengan hukum. Berhadapan dengan hukum berarti anak tersebut dapat menjadi korban atau saksi, sedangkan berkonflik dengan hukum berarti anak tersebut berada di posisi sebagai tersangka atau terdakwa tindak pidana. ${ }^{1}$

Tidak dapat dipungkiri maraknya lalu lintas perdagangan narkotika dan psikotropika di Indonesia berasal posisi Indonesia yang terletak diantara dua benua dan dua samudra, yang mengelilingi Indonesia membuat lalu lintas perdagangan menjadi lebih mudah. Tanah Indonesia juga subur untuk kultivas gelap tanaman ganja juga berpotensi pada tingkat penyalahgunaan ganja. ${ }^{2}$

Penyalahgunaan narkotika sudah sampai pada taraf memprihatinkan, bukan hanya kuantitas penyalahgunaannya yang semakin banyak dan meluas akan tetapi penggunanya juga telah menjalar hampir ke setiap lapisan masayarakat mulai dari anak dibawah umur, pelajar, hingga pejabat negara pun terlibat dalam tindak pidana

1 Hadi Supeno, "Kriminalisasi anak, Tawaran Gagasan Radikal Peradilan Anak Tanpa Pemidanaan”, Jakarta:PT. Gramedia, 2010, Hal 89

${ }^{2}$ Lydia Harlina Martono \& Satya Joewana, MembantuPemulihan Pecandu Narkotika dan Keluarga, Balai Pustaka, Jakarta, 2005, hlm. 1 
narkotika ini. $^{3}$ Peredaran narkotika di Indonesia mempunyai kecenderungan meningkat dan yang sangat menjadi perhatian besar pengguna narkotika saat ini mulai dilakukan oleh aparat pemerintahan bahkan para penegak hukum. ${ }^{4}$

Undang-Undang Nomor 35 tahun 2009 tentang Narkotika yang saat ini digunakan untuk mengatur, mengawasi dan menindak peredaran dan penyalahgunaan Narkotika tidaklah serta merta dapat mengendalikan peredaran dan penyalahgunaan Narkotika di Indonesia. Karena Narkotika dapat dengan mudah membuat seseorang kecanduan bahkan samapai tidak bisa berhenti untuk mengkonsumsinya sampai akhirnya berakibat pada kematian yang cepat dan tidak wajar.

Sejalan dengan meningkatnya penyalahgunaan narkoba, pemerintah melakukan penindakan tegas para sindikat dan pengedar dengan memberikan hukuman berat, bahkan sampai hukuman mati. Selain itu bagi korban pengguna atau pecandu, pemerintah telah mengupayakan untuk mengurangi dampak buruk akibat penggunaan narkoba yaitu dengan cara memberikan fasilitas rehabilitasi, baik secara medis maupun sosial. Hal ini dilakukan agar korban pengguna narkoba dapat kembali sembuh, menjadi manusia produktif, mampu bekerja memenuhi kebutuhan kehidupan serta keluarganya, dan menjadi generasi bangsa yang sehat dan kuat.

Namun kebijakan untuk menempatkan korban pengguna narkoba di tempat rehabilitasi tidak dapat berjalan secara baik karena masih terbentur dengan ketentuan Undang-Undang Nomor 35 Tahun 2009 tentang Narkotika yang dalam hal ini korban pengguna narkoba sampai sekarang ini masih diposisikan sebagai pelaku tindak pidana, akibatnya mereka tidak memperoleh perawatan dan pemulihan secara maksimal karena harus mendekam di dalam penjara.

Dalam konteks pemidanaan korban penyalahgunaan narkoba, permasalahan muncul ketika ancaman pidana yang dirumuskan Undang-Undang Nomor 35 Tahun 2009 tentang Narkotika, masih terdapat kontraindiksi, kerancuan, ketidaksesuaian, dan juga keragamaan dalam menerapkan produk hukum tersebut, terutama dalam menentukan sanksinya. ${ }^{5}$ Di satu sisi, pengguna narkoba dipidana penjara, di sisi lain direhabilitasi.

Meskipun Undang Undang telah menyebutkan secara jelas bahwa korban pengguna narkoba berhak menjalani pengobatan dan/atau perawatan melalui rehabilitasi, namun pada kenyataannya jarang sekali Hakim memilih menjatuhkan hukuman rehabilitasi. Berdasar fakta, walau diwajibkan untuk merehabilitasi tetapi pemidanaan yang diterapkan terhadap korban pengguna narkoba masih berupa pidana penjara.

Dari penjelasan di atas maka muncul beberapa permasasalahan yang akan dibahas yaitu: (1). Apakah penerapan hukuman penjara bagi seorang pengguna telah sesuai dengan prespektif Undang-Undang Nomor 35 Tahun 2009 tentang Narkotika?; dan (2). Bagaimanakah upaya optimalisasi pemberian hak rehabilitasi bagi pengguna

\footnotetext{
${ }^{3}$ Ali Johardi. (2021). Kompol Yuni Dalam Pusaran Kasus Penyalahgunaan Narkoba; Sebagai Pelaku Atau Korban?. KRTHA BHAYANGKARA, 15(1). https://doi.org/10.31599/krtha.v15i1.596

${ }^{4}$ Dahlan, Problematika Keadilan dalam Penerapan Pidana terhadap Penyalah Guna Narkotika, Yogyakarta: Deepublish Yogyakarta., 2017, hlm. 4.

5 Ali Johardi. (2021). Rumitnya Eksekusi Mati Terhadap Terpidana Mati Narkotika. Jurnal Hukum Sasana, 7(1). https://doi.org/10.31599/sasana.v7i1.486
} 
narkotika dalam prespektif Undang-Undang Nomor 35 Tahun 2009 tentang Narkotika?

\section{METODE PENELITIAN}

Metode yang digunakan dalam penelitian ini adalah dengan pendekatan yuridis normatif yaitu dengan melakukan penelitian berdasarkan pada bahan-bahan hukum / referensi dengan cara menelaah teori-teori dan konsep-konsep dari bahan-bahan hukum tersebut, yang berkaitan dengan asas-asas hukum peraturan perundangundangan yang berhubungan dengan penulisan / penelitian ini.

\section{PEMBAHASAN}

\section{A. Sanksi Pidana Terhadap Pengguna Dalam Tindak Pidana Penyalahgunaan Narkotika Berdasarkan Prespektif Undang-Undang Nomor 35 Tahun 2009 Tentang Narkotika}

Perkembangan tindak pidana penyalahgunaan narkotika telah menjadi suatu hal yang penting untuk diatasi sehingga munculah istilah Indonesia saat ini dalam situasi “Darurat Narkoba”. Segala upaya dilakukan oleh BNN bersama Polri, TNI, Bea Cukai, Imigrasi, Pemerintah Daerah dan instansi terkait lainnya serta seluruh komponen masyarakat guna bersinergi dan bersama-sama mengambil langkah strategis dalam upaya penanggulangan terhadap penyalahgunaan dan peredaran gelap narkotika di Indonesia. Beberapa upaya-upaya yang telah dilaksanakan secara komprehensif dan berkesinambungan adalah dengan mengimplementasikan secara seimbang antara supply reduction (pengurangan pasokan) melalui Upaya Pemberantasan, dengan demand reduction (pengurangan permintaan) melalui Upaya Pencegahan.

Umumnya, jenis-jenis tindak pidana Narkotika dapat dibedakan menjadi berikut ini:

1) Tindak pidana yang menyangkut penyalahgunaan Narkotika. Tindak pidana penyalahgunaan Narkotika dibedakan menjadi dua macam yaitu perbuatannya untuk orang lain dan untuk diri sendiri.

2) Tindak pidana yang menyangkut produksi dan jual beli Narkotika Tindak pidana yang menyangkut produksi dan jual beli disini bukan hanya dalam arti sempit, akan tetapi termasuk pula perbuatan ekspor impor dan tukar menukar Narkotika.

3) Tindak pidana yang menyangkut pengangkutan Narkotika

4) Tindak pidana yang menyangkut penguasaan Narkotika

5) Tindak pidana yang menyangkut tidak melaporkan pecandu Narkotika

6) Tindak pidana yang menyangkut label dan publikasi

7) Tindak pidana yang menyangkut penyitaan dan pemusnahan Narkotika

8) Tindak pidana yang menyangkut pemanfaatan anak dibawah umur dalam tindak pidana dibidang Narkotika.

Di dalam tindak pidana penyalahgunaan narkotika perlu dipahami adanya beberapa pihak yang terlibat. Sudah pasti jika berbicara tindak pidana maka, haruslah 
ada seorang pelaku. Dalam tindak pidana penyalahgunaan narkotika dikenal istilah pengedar, pengguna dan pengguna yang juga merupakan pengedar.

Pemakai atau pecandu narkotika dalam perspektif hukum merupakan seorang pelaku pidana. Namun, apabila dicermati dengan lebih seksama, banyak kalangan berpendapat bahwa sebenarnya mereka merupakan korban dari sindikat atau mata rantai peredaran dan perdagangan narkotika, psikotropika dan obat terlarang. Pecandu merupakan pangsa pasar utama sebagai "pelanggan tetap". Secara psikologis, mereka sulit melepaskan diri dari ketergantungan, walaupun mungkin, sebenarnya mereka ingin lepas dari jeratan narkotika yang membelitnya. Pecandu memerlukan penanganan yang berbeda dalam proses pemidanaannya. Berdasarkan pandangan tersebut, maka "penghukumannya" pun pelru dilakukan tersendiri, dengan pola penanganan, pembinaan, dan perlakuan yang berbeda pula.

Pengguna narkotika sebagai pelaku tindak pidana dan sekaligus sebagai korban, dengan berdasarkan pada Pasal 103 UU Narkotika, Mahkamah Agung RI mengeluarkan terobosan dengan mengeluarkan beberapa surat edaran, antara lain :

Surat Edaran Mahkamah Agung RI (SEMA) No. 07 Tahun 2009 tentang Menempatkan Pemakai Narkoba ke Dalam Panti Terapi dan Rehabilitasi yang dituangkan ke dalam Surat No. 07/BUA.6/HS/SP/III/2009 tertanggal 17 Maret 2009 (selanjutnya disingkat SEMA No. 07 Tahun 2009); Surat Edaran Mahkamah Agung RI (SEMA) No. 04 Tahun 2010 tentang Penetapan Penyalahgunaan, dan Pecandu Narkotika ke Dalam Lembaga Rehabilitasi Medis dan Rehabilitasi Sosial (selanjutnya disingkat SEMA No. 04 Tahun 2010).

Adapun SEMA No. 07 Tahun 2009 tentang Menempatkan Pemakai Narkoba ke Dalam Panti Terapi dan Rehabilitasi, bagi pecandu dan pengguna narkotika sebagai pelaku tindak pidana narkotika harus dimasukkan ke dalam Panti Rehabilitasi yang ada di seluruh Indonesia. Tetapi Surat Edaran ini tidak mewajibkan kepada setiap hakim untuk menjatuhkan sanksi tindakan melainkan hanya tuntunan kepada pecandu dan pengguna narkotika sebagai pelaku tindak pidana narkotika dan psikotropika agar dimasukkan ke dalam panti rehabilitasi.

Undang-Undang No. 35 Tahun 2009 tentang Narkotika telah mengatur jenisjenis sanksi yang diberikan pada tindak pidana narkotika antara lain:

a) Tindak Pidana bagi penyalah guna atau sebagai korban penyalahgunaan narkotika, penyalah guna tersebut wajib menjalani rehabilitasi medis dan rehabilitasi sosial.

b) Tindak Pidana Orang Tua / Wali dari Pecandu Narkotika Narkotika yang Belum Cukup Umur (Pasal 128) dipidana dengan pidana kurungan paling lama 6 (enam) bulan atau pidana denda paling banyak Rp1.000.000,00 (satu juta rupiah).

c) Tindak Pidana yang Dilakukan oleh Korporasi (Pasal 130) Dipidana dengan pidana penjara dan pidana denda dengan pemberatan 3 (tiga) kali. Korporasi dapat dijatuhi korporasi dapat dijatuhi pidana tambahan berupa: a. pencabutan izin usaha dan/atau b. pencabutan status badan hukum.

d) Tindak pidana bagi Orang yang Tidak Melaporkan Adanya Tindak Pidana Narkotika (Pasal 131). Dipidana dengan pidana penjara paling lama 1 (satu) tahun atau pidana denda paling banyak Rp50.000.000,00 (lima puluh juta rupiah).

e) Tindak Pidana terhadap Percobaan dan Permufakatan Jahat Melakukan Tindak Pidana Narkotika dan Prekursor (Pasal 132) Ayat (1), dipidana dengan pidana pidana penjara yang sama sesuai dengan ketentuan 
sebagaimana dimaksud dalam Pasal-Pasal tersebut. Ayat (2), dipidana pidana penjara dan pidana denda maksimumnya ditambah $1 / 3$ (sepertiga).

f) Tindak Pidana bagi Menyuruh, Memberi, Membujuk, Memaksa dengan Kekerasan, Tipu Muslihat, Membujuk Anak (Pasal 133) ayat (1), dipidana dengan pidana mati atau pidana penjara seumur hidup, atau pidana penjara paling singkat 5 (lima) tahun dan paling lama 20 (dua puluh) tahun dan pidana denda paling sedikit Rp2.000.000.000,00 (dua miliar rupiah) dan paling banyak Rp20.000.000.000,00 (dua puluh miliar rupiah). ayat (2), dipidana dengan pidana penjara paling singkat 5 (lima) tahun dan paling lama 15 (lima belas) tahun dan pidana denda paling sedikit Rp1.000.000.000,00 (satu miliar rupiah) dan paling banyak Rp10.000.000.000,00 (sepuluh miliar rupiah).

g) Tindak Pidana bagi Pecandu Narkotika yang Tidak Melaporkan Diri (Pasal 134) ayat (1), dipidana dengan pidana kurungan paling lama 6 (enam) bulan atau pidana denda paling banyak Rp2.000.000,00 (dua juta rupiah). ayat (2), dipidana dengan pidana kurungan paling lama 3 (tiga) bulan atau pidana denda paling banyak Rp1.000.000,00 (satu juta rupiah).

h) Tindak Pidana bagi Pengurus Industri Farmasi yang Tidak Melaksanakan Kewajiban (Pasal 135). Dipidana dengan pidana penjara paling singkat 1 (satu) tahun dan paling lama 7 (tujuh) tahun dan pidana denda paling sedikit Rp40.000.000,00 (empat puluh juta rupiah) dan paling banyak Rp400.000.000,00 (empat ratus juta rupiah).

i) Tindak Pidana terhadap Hasil-Hasil Tindak Pidana Narkotika dan/atau Prekursor Narkotika (Pasal 137) huruf (a), dipidana dengan pidana penjara paling singkat 5 (lima) tahun dan paling lama 15 (lima belas) tahun dan pidana denda paling sedikit Rp1.000.000.000,00 (satu miliar rupiah) dan paling banyak Rp10.000.000.000,00 (sepuluh miliar rupiah). Huruf (b), dipidana dengan pidana penjara paling singkat 3 (tiga) tahun dan paling lama 10 (sepuluh) tahun dan pidana denda paling sedikit Rp500.000.000,00 (lima ratus juta rupiah) dan paling banyak Rp5.000.000.000,00 (lima miliar rupiah).

j) Tindak Pidana terhadap Orang yang Menghalangi atau Mempersulit Penyidikan, Penuntutan dan Pemeriksaan Perkara (Pasal 138) Dipidana dengan pidana penjara paling lama 7 (tujuh) tahun dan pidana denda paling banyak Rp500.000.000,00 (lima ratus juta rupiah).

k) Tindak Pidana bagi Nahkoda atau Kapten Penerbang yang Tidak Melaksanakan Ketentuan Pasal 27 dan Pasal 28 (Pasal 139) dipidana dengan pidana penjara paling singkat 1 (satu) tahun dan paling lama 10 (sepuluh) tahun dan pidana denda paling sedikit Rp100.000.000,00 (seratus juta rupiah) dan paling banyak Rp1.000.000.000,00 (satu miliar rupiah).

1) Tindak Pidana bagi PPNS, Penyidik Polri, Penyidik BNN yang Tidak Melaksanakan Ketentuan tentang Barang Bukti (Pasal 140) dipidana dengan pidana penjara paling singkat 1 (satu) tahun dan paling lama 10 (sepuluh) tahun dan pidana denda paling sedikit Rp100.000.000,00 (seratus juta rupiah) dan paling banyak Rp1.000.000.000,00 (satu miliar rupiah).

m)Tindak Pidana bagi Kepala Kejaksaan Negeri yang Tidak Melaksanakan Ketentuan Pasal 91 Ayat(1) (Pasal 141) dipidana dengan pidana penjara paling singkat 1 (satu) tahun dan paling lama 10 (sepuluh) tahun dan pidana denda paling sedikit Rp100.000.000,00 (seratus juta rupiah) dan paling banyak Rp1.000.000.000,00 (satu miliar rupiah). 
n) Tindak Pidana bagi Petugas Laboratorium yang Memalsukan Hasil Pengujian (Pasal 142) dipidana dengan pidana penjara paling lama 7 (tujuh) tahun dan pidana denda paling banyak Rp500.000.000,00 (lima ratus juta rupiah).

o) Tindak Pidana bagi Saksi yang Memberikan Keterangan Tidak Benar (Pasal 143) dipidana dengan pidana penjara paling singkat 1 (satu) tahun dan paling lama 10 (sepuluh) tahun dan pidana denda paling sedikit Rp 60.000.000,00 (enam puluh juta rupiah) dan paling banyak Rp 600.000.000,00 (enam ratus juta rupiah).

p) Tindak Pidana bagi Setiap Orang yang Melakukan Pengulangan Tindak Pidana (Pasal 144) dipidana dengan pidana maksimumnya ditambah dengan $1 / 3$ (sepertiga).

Tindak Pidana yang dilakukan Pimpinan Rumah Sakit, Pimpinan Lembaga Ilmu Pengetahuan, Pimpinan Industri Farmasi, dan Pimpinan Pedagang Farmasi (Pasal 147) dipidana dengan pidana penjara paling singkat 1 (satu) tahun dan paling lama 10 (sepuluh) tahun dan pidana denda paling sedikit Rp100.000.000,00 (seratus juta rupiah) dan paling banyak Rp 1.000.000.000,00 (satu miliar rupiah).

Pemidanaan terhadap pelaku pengguna Narkoba tidak dapat dipisahkan dari sistem pemidanaan yang dianut oleh sistem hukum di Indonesia. Tujuan sistem pemidanaan pada hakekatnya merupakan operasionalisasi penegakan hukum yang dijalankan oleh sistem peradilan berdasarkan perangkat hukum yang mengatur berupa kriminalisasi penyalahgunaan dan peredaran gelap Narkoba yakni Undang-Undang Nomor 35 Tahun 2009 tentang Narkotika sebagai pengganti Undang-Undang No. 22 Tahun 1997 tentang Narkotika. ${ }^{6}$

Sanksi pidana yang dijatuhkan kepada pecandu narkotika sebagai self victimizing victims adalah dalam bentuk menjalani masa hukuman dalam penjara, sedangkan sanksi tindakan yang diberikan kepada pecandu narkotika sebagai korban adalah berupa pengobatan dan/atau perawatan yang diselenggarakan dalam bentuk fasilitas rehabilitasi. Sistem pelaksanaannya adalah masa pengobatan dan/atau perawatan dihitung sebagai masa menjalani hukuman.

Kerangka yuridis yang termaktub di dalam Undang-Undang Nomor 35 Tahun 2009 tentang Narkotika seharusnya digunakan oleh hakim dalam memutus pengguna Narkoba. Dimana menempatkan penyalahguna/pengguna narkotika ke dalam lembaga rehabilitasi melalui putusan hakim merupakan alternatif pemberian sanksi pidana yang sangat baik dalam rangka deferent aspect dan refomaive aspect pelaku penyalahgunaan Narkoba dan penanggulangan peredaran gelap Narkoba bila dibandingkan dengan menerapkan pelaku dengan sanksi pidana penjara, sanksi pidana berupa rehabilitasi dilakukan melalui rehabilitasi medis maupun rehabilitasi sosial.

Rehabilitasi dimaksud bertujuan agar pengguna narkotika terlepas dari ketergantungan. Guna menguatkan hal tersebut Mahkamah Agung (MA) mengeluarkan sebuah surat edaran untuk memberikan petunjuk bagi para hakim, yaitu Surat Edaran Mahkamah Agung Nomor 04 Tahun 2010 tentang Penempatan Penyalahgunaan, Korban Penyalahgunaan dan Pecandu Narkotika ke dalam Lembaga Rehabilitasi Medis dan Rehabilitasi Sosial yang merupakan revisi dari Surat Edaran Mahkamah Agung Nomor 07 Tahun 2009. ${ }^{7}$

\footnotetext{
${ }^{6}$ Jurnal Negara Hukum: Vol. 2, No. 2, November 2011.

7 Amin, R. . (2020). Analisis Perlindungan Hukum Saksi Pelaku Yang Bekerjasama (Justice Collaborator) Perkara Tindak Pidana Narkotika Dalam Sistem Peradilan Pidana Di Indonesia. Jurnal Hukum Sasana, 6(2). https://doi.org/10.31599/sasana.v6i2.271
} 


\section{B. Upaya Optimalisasi Pemberian Hak Rehabilitasi Bagi Pengguna Narkotika}

\section{Berdasarkan Undang - Undang No. 35 Tahun 2009 Tentang Narkotika}

Undang-Undang Nomor 35 Tahun 2009 Tentang Narkotika telah memberi perlakuan yang berbeda bagi pelaku penyalahgunaan narkotika, sebelum undang-undang ini berlaku tidak ada perbedaan perlakuan antara pengguna pengedar, bandar, maupun produsen narkotika. Pengguna atau pecandu narkotika di satu sisi merupakan pelaku tindak pidana, namun di sisi lain merupakan korban.

Pengguna atau pecandu narkotika menurut undang-undang sebagai pelaku tindak pidana narkotika adalah dengan adanya ketentuan Undang-Undang Narkotika yang mengatur mengenai pidana penjara yang diberikan pada para pelaku penyalahgunaan narkotika. Kemudian di sisi lain dapat dikatakan bahwa menurut Undang-Undang Narkotika, pecandu narkotika tersebut merupakan korban adalah ditunjukkan dengan adanya ketentuan bahwa terhadap pecandu narkotika dapat dijatuhi vonis rehabilitasi.

Pecandu narkotika merupakan "self victimizing victims", karena pecandu narkotika menderita sindroma ketergantungan akibat dari penyalahgunaan narkotika yang dilakukannya sendiri. Pasal 54 Undang-Undang Nomor 35 Tahun 2009 tentang Narkotika menyatakan bahwa: "Pecandu narkotika dan korban penyalahgunaan narkotika wajib menjalani rehabilitasi medis dan rehabilitasi social."

Merujuk perspektif tanggung jawab korban, adanya self-victimizing victims yakni pelaku yang menjadi korban karena kejahatan yang dilakukannya sendiri. Hal ini sering dinyatakan sebagai kejahatan tanpa korban ${ }^{8}$. Akan tetapi, pandangan ini menjadi dasar pemikiran bahwa tidak ada kejahatan tanpa korban. Semua atau setiap kejahatan melibatkan 2 (dua) hal, yaitu penjahat dan korban. Sebagai contoh dari selfvictimizing victims adalah pecandu obat bius, alkoholisme, homoseks, dan judi. Hal ini berarti pertanggungjawaban terletak penuh pada si pelaku, yang juga sekaligus merupakan korban.

Selain itu, pecandu narkoba dapat juga dikategorikan sebagai kejahatan tanpa korban (crime without victim). Pengertian kejahatan tanpa korban berarti kejahatan ini tidak menimbulkan korban sama sekali akan tetapi si pelaku sebagai korban. Sementara dalam katagori kejahatan, suatu perbuatan jahat haruslah menimbulkan korban dan korban itu adalah orang lain (an act must take place that involves harm inflicted on someone by the ac-tor). Artinya apabila hanya diri sendiri yang menjadi korban maka hal tersebut tidak dapat dikatakan sebagai kejahatan.

Tindak pidana atau perbuatan melawan hukum dilakukan oleh seseorang kepada or-ang lain, kalau tidak ada pihak lain yang menjadi korban maka sebagaimana diputuskan Mahkamah Konstitusi melalui Putusan Nomor 1/PUU-IX/2011, tidaklah dapat dikatakan sebagai tindak pidana atau delik (delict) karena sifat umum tindak pidana adalah perbuatan melawan hukum yaitu perbuatan yang melanggar norma sedemikian rupa sehingga mencederai kepentingan hukum or-ang lain atau membahayakan kepentingan orang lain. Putusan pengadilan Mahkamah Konstitusi ini diambil untuk menguatkan pendapat para pakar hukum sekaligus meyakinkan peneliti bahwa korban karena perbuatannya sendiri bukanlah suatu tindak pidana. Dengan

${ }^{8}$ Dikdik M Arief Manshur dan Elisatris Gultom. 2007. Urgensi Perlindungan Korban Kejahatan. Jakarta: PT Raja Grafindo Persada, hlm. 125. 
demikian, seseorang yang menggunakan narkoba untuk dirinya sendiri dan perbuatan tersebut tidak merugikan dan/ atau menyebabkan terjadinya korban, maka pengguna tersebut tidak dapat dikatagorikan sebagai perbuatan kejahatan.

Pasal 128 Ayat (2) Undang-Undang Nomor No. 35 tahun 2009 tentang Narkotika tersebut, disimpulkan bahwa pecandu narkotika yang ketika ditangkap telah menjalani 2 (dua) kali masa perawatan dokter akan diproses secara hukum, dan tidak lagi diberikan kesempatan untuk dapat mengakses layanan rehabilitasi medis. Hal ini bertentangan dengan konsep ketergantungan yang mengenal adanya fenomena relapse atau kambuh. Ketergantungan sebagai sebuah sindrom memiliki arti sebagai serangkaian sindrom perilaku, kognitif, dan fisiologis yang terbangun akibat penggunaan zat secara terus menerus. Salah satu fenomena dari ketergantungan adalah perilaku untuk terus menggunakan narkotika terlepas dari kesadaran akan bahaya narkotika itu sendiri. WHO mengartikan ketergantungan narkotika sebagai gangguan yang kronis dan mudah kambuh dengan dasar biologis dan genetik, dan kekambuhan tersebut tidak semata-mata karena ketiadaan keinginan untuk berhenti menggunakan.

Pemberian hak rehabilitasi terhadap pengguna narkotika di Indonesia jika melihat dari Undnag- Undang Nomor 35 Tahun 2009 Tentang Narkotika belum dapat dilaksanakan secara maksimal karena terdapat beberapa kendala yaitu :

1. Kendala internal Pemenuhan hak rehabilitas bagi penyalahguna narkotika memiliki berbagai kendala yang disebabkan oleh faktor internal yang menghambat proses rehabilitasi bagi penyalahguna narkotika. Voluntari merupakan kesadaran atau kerelaan penyalahguna narkotika yang telah berusia cukup umur untuk melaporkan diri ke institusi penerimaan wajib lapor atau dilaporkan oleh keluarga penyalahguna narkotika apabila penyalahguna narkotika masih belum cukup umur. Kendala internal pemenuhan rehabilitasi dari segi voluntari yaitu individu sebagai penyalahguna narkotika memiliki rasa malu terhadap keluarga dan lingkungan tempat tinggal sehingga tidak memiliki keinginan untuk melaporkan diri ke institusi penerimaan wajib lapor. Keinginan individu untuk tetap menikmati narkotika membuat kendala dalam proses voluntary. Rasa takut pemidanaan juga merupakan kendala bagi penyalahguna narkotika dalam melaporkan diri kepada institusi wajib lapor. Compulsary merupakan program wajib lapor dimana penyalahguna narkotika yang telah melalui proses persidangan diwajibkan untuk menjalani proses rehabilitasi berdasarkan putusan dari pengadilan. Faktor internal yang menjadi kendala dari segi compulsary yakni adanya keinginan kuat kepolisian dalam penegakkan hukum (law enforcement).

2. Kendala eksternal Upaya pemenuhan hak rehabilitasi bagi penyalahguna narkotika melalui voluntary dan compulsari memiliki kendala eksternal yang mengakibatkan pemenuhan hak rehabilitasi menjadi tidak optimal. Kendala dari pemenuhan hak rehabilitasi secara voluntary, maka faktor keluarga menjadi salah satu dari kendala eksternal karena penyalahguna narkotika ditekan oleh pihak keluarga untuk tidak melaporkan diri kepada institutsi penerimaan wajib lapor karena akan membuat nama keluarga menjadi tercoreng. Faktor ekternal yang menjadi kendala dalam pemenuhan hak rehabilitasi bagi penyalahguna narkotika dari compulsary yakni setelah adanya putusan rehabilitasi dari pengadilan maka penyalahguna narkotika secepatnya harus menjalani proses rehabilitasi, farktor eksternal yang menjadi kendala dalam pemenuhan hak rehabilitasi penyalahguna narkotika adalah sampai saat ini kurangnya fasilitas yang memadai supaya rehabilitasi bagi penyalahguna narkotika dapat berjalan secara optimal. 


\section{KESIMPULAN}

Dari penjabaran diatas dapat ditarik kesimpulan bahwa penerapan hukuman penjara bagi seorang pengguna belum cukup sesuai dengan prespektif Undang-Undang Nomor 35 Tahun 2009 tentang Narkotika karena Undang-Undang Nomor 35 Tahun 2009 tentang Narkotika mengatur mengenai hak rehabilitasi bagi pengguna narkotika yaitu menempatkan penyalahguna/pengguna narkotika ke dalam lembaga rehabilitasi melalui putusan hakim sebab hal ini adalah alternatif pemberian sanksi pidana yang sangat baik dalam rangka deferent aspect dan refomaive aspect pelaku penyalahgunaan narkotika dan penanggulangan peredaran gelap narkotika bila dibandingkan dengan menerapkan pelaku dengan sanksi pidana penjara. Penerapan hak rehabilitasi terhadap pengguna narkotika di Indonesia belum optimal dikarenakan beberapa kendala baik dari segi internal, eksternal dan regulasi hukum.

\section{SARAN}

Aparat penegak hukum dalam hal menjatuhkan hukuman bagi pengguna penyalahgunaan narkotika hendakya dapat memberikan hukuman yang dapat menimbulkan kemanfaatan bagi penegakan hukum sehingga pelaku tidak mengulangi lagi perbuatannya. Seperti penerapan hukuman rehabiltasi terhadap pelaku penyalahgunaan narkotika sebagai hukuman utama. Pemerintah pun hendaknya membuat aturan hukum yang tegas dan jelas dalam mengatur tata cara penerapan dan perolehan hak rehabilitasi bagi pengguna penyalahgunaan narkotika, agar para pengguna dapat terlepas dari ketergantungan narkotika namun tetap bertanggungjawab atas perbuatannya dalam hal melanggar ketentuan perundang- undangan yang berlaku. Selain itu pemerintah hendaknya dapat memberikan pembatasan yang tegas terkait penerapan sanksi hukuman bagi pengedar dan pengguna narkotika agar tujuan pemidanaan yang berkepastian hukum, adil dan memiliki kemanfaatan dapat tercapai.

\section{DAFTAR PUSTAKA}

\section{Buku}

Aaron T. Beck. Cognitive Therapy of Substance Abuse. New York: The Guilford Press, 1993.

Abidin Az, Andi Hamzah. Hukum Pidana Indonesia. Jakarta: PT. Yasrif Watampone, 2010.

Amir Ilyas, Asas-asas Hukum Pidana, Rangkang Education, Yogyakarta, 2012.

Andrisman, Tri. Asas-Asas dan Dasar Aturan Hukum Pidana Indonesia, Yogyakarta : Liberty, 2009.

Andi Sofyan dan Nur Azisa, Hukum Pidana,Pustaka Pena Press, Makassar, 2016.

A.R. Sujono dan Bony Daniel, Komentar dan Pembahasan Undang-Undang Nomor 35 Tahun 2009 Tentang Narkotika. Jakarta: Sinar Grafika, 2011. 
Chazawi, Adami. Pelajaran Hukum Pidana I: Stelsel Pidana, Tindak Pidana, Teori-Teori Pemidanaan Dan Batas Berlakunya Hukum Pidana, Jakarta : Raja Grafindo Persada, 2005.

Dahlan, Problematika Keadilan dalam Penerapan Pidana terhadap Penyalah Guna Narkotika, Yogyakarta: Deepublish Yogyakarta,2017.

Departemen Pendidikan Nasional, 2012,Kamus Besar Bahasa Indonesia, PT. Gramedia Pustaka 8 M. Marwan dan Jimmy P.,Kamus Hukum, Reality Publisher, Surabaya, 2009.

Dikdik M Arief Manshur dan Elisatris Gultom, Urgensi Perlindungan Korban Kejahatan. Jakarta: PT Raja Grafindo Persada, 2007.

E.Y. Kanter, S.R. Sianturi, Asas-asas Hukum Pidana di Indonesia dan Penerapannya, Storia Grafika, Jakarta, 2002.

Glenn Greenwald, Drug Decriminalization in Portugal; Lessons for Creating Fairand Successful Drug Policies. USA: Cato Institute, 2009.

Hakim, Lukman, Asas-asas Hukum Pidana, Yogyakarta : Deepublish, 2020.

Hadjon, Phillipus M. Perlindungan Hukum Bagi Rakyat Indonesia, Surabaya : Bina Ilmu, 1987.

Harlina Martono, Lydia \& Satya Joewana, Membantu Pemulihan Pecandu Narkotika dan Keluarga, Balai Pustaka, Jakarta,2005.

Hari sasangka, Narkotika dan Psikotoprika Dalam Hukum Pidana, Mandar Maju,Jakarta, 2003.

Hendrojono. Sosiologi Hukum (Pengaruh Perubahan Masyarakat dan Hukum). Surabaya : Srikandi, 2005

Lamintang, P.A.F, Dasar-dasar Hukum Pidana Indonesia, Citra Aditya Bakti, Bandung, 1997.

Marzuki, Peter Mahmud. Penelitian Hukum, Jakarta,:Kencana Prenada, 2010

Makaro, Moh Taufik, Et. Al, Tindak Pidana Narkotika, PT Ghalia Indonesia, Bogor, 2005.

Mertokusumo, Sudikno. Mengenal Hukum, Yogyakarta: Liberty, 1991.

Liberty, 2009.

.Penemuan hukum sebuah pengantar, Yogyakarta :

Mustafa, Muhammad, Krimonologi: Kajian Sosiologi terhadap Kriminalitas, Perilaku menyimpang, dan Pelanggar Hukum, FISIP UI Press, 2007.

Moleong. Lexy. J. Metodologi Penelitian Kualitatif, Bandung : Remaja Rosdakarya, 2007.

Nasution. Metode Research (Penelitian Ilmiah). Jakarta: Bumi Aksara, 2003.

Nasution, Aulia Rosa, Terorisme sebagai Kejahatan terhadap Kemanusian, Jakarta: Kencana Prenada Media Group, 2012.

Phillipus M. Hadjon, Perlindungan Hukum Bagi Rakyat Indonesia, Surabaya : Bina Ilmu, 1987. 
Salim peter dan Slim yuni, kamus bahasa indonesia kontemporer, modern english pers, jakarta, 1991

Satori, Djam'an. Profesi Keguruan. Jakarta: Universitas Terbuka, 2007.

Sri Utari, Indah, Aliran dan Teori Dalam Kriminologi, Yogyakarta : Thafa Media, 2012.

Soekanto, Soerjono .Pengantar Penelitian Hukum, Jakarta : Universitas Indonesia Press, 1984.

Soeprapto, Maria Farida Indrati Ilmu Perundang-Undangan : Jenis, Fungsi, dan Materi Muatan, Yogyakarta : Kanisius, 2010.

Sudarsono, Kamus Hukum Edisi Baru, Jakarta : Rineka Cipta, 2007.

Soedarto, Hukum dan Hukum Pidana. Bandung: PT Alumni, 2007.

Sugiyono. Cara Mudah Menyusun Skripsi, Tesis, dan Disertasi. Bandung : Mandar Maju, 2007.

Tanzeh, Ahmad. Pengantar Metode Penelitian, Yogyakarta : Teras, 2009.

Taufik makarao, dkk, Tindak Pidana Narkotika, Ghalia Indonesia, Jakarta, 2003,

Utari, Indah Sri. Aliran dan Teori Dalam Kriminologi, Yogyakarta : Thafa Media, 2012.

\section{Peraturan Perundang-Undangan}

Undang-Undang Dasar Negara Republik Indonesia Tahun 1945

Republik Indonesia Undang-Undang Nomor 1 Tahun 1946 jo Undang-Undang Nomor

73 Tahun 1958 tentang Kitab Undang-Undang Hukum Pidana (KUHP)

Republik Indonesia Undang-Undang Nomor 8 Tahun 1981 tentang Kitab UndangUndang Hukum Acara Pidana (KUHAP)

Republik Indonesia Undang-Undang Nomor 22 tahun 1997 tentang Psikotropika

Republik Indonesia Undang-Undang Nomor No. 5 tahun 1997 tentang Narkotika

Republik Indonesia Undang-Undang Nomor No. 35 tahun 2009 tentang Narkotika

Draft Naskah Akademis Rancangan Undang-Undang Narkotika versi BNN Tahun 2017

Surat Edaran Jaksa Agung Nomor 002/A/JA/02/2013 tentang Penempatan Pecandu Narkotika Pada Lembaga Rehabilitasi.

Surat Edaran Mahkmah Agung Nomor 3 tahun 2011 tentang Penempatan Korban Penyalahugunaan Narkotika di Lembaga Rehabilitasi.

Surat Edaran Mahkamah Agung Nomor 4 tahun 2010 tentang Penempatan Penyalahgunaan, Korban Penyalahgunaan dan Pecandu Narkotika ke dalam Lembaga Rehabilitasi Medis dan Rehabilitasi Sosial.

Surat Edaran Mahkamah Agung (SEMA) Nomor 07 tahun 2009 tentang Menempatkan Pemakai Narkoba ke dalam Panti Terapi dan Rehabilitasi.

Peraturan Bersama Ketua Mahkamah Agung Republik Indonesia, Menteri Hukum Dan Hak Asasi Manusia Republik Indonesia, Menteri Kesehatan Republik 
Indonesia, Menteri Sosial Republik Indonesia, Jaksa Agung Republik Indonesia, Kepala Kepolisian Negara Republlk Indonesia dan Kepala Badan Narkotika Nasional Republik Indonesia NOMOR: 01/PB/MA/III/2014 NOMOR: 03 TAHUN 2014 NOMOR: 11/TAHUN 2014 NOMOR: 03 TAHUN 2014 NOMOR: PER-005/A/JA/03/2014 NOMOR: 1 TAHUN 2014 NOMOR: PERBER/01/III/2014/BNN tentang Penanganan Pecandu Narkotika dan Korban Penyalahgunaan Narkotika Ke dalam Lembaga Rehabilitasi.

\section{Jurnal}

Yustisia Vol.1 No. 3 September - Desember 2012 Model Pemidanaan yang Ideal bagi Korban

http://journal.1ldikti9.id/plenojure Vol 9, No, 1, April 2020, pp 58-71 p-ISSN: 23017686 dan e-ISSN: 2684-8449 https://doi.org/10.37541/plenojure.v9i1.390 Analisis Sanksi Pidana Terhadap Pelaku Tindak Pidana Narkotika

ADIL: Jurnal Hukum Vol. 7 No. Penerapan Hukum Pidana Narkotika Di Indonesia

Jurnal Hukum, Vol XXVIII, No. 2, Desember 2012 Implementasi Kebijakan POLRI Terhadap Pelaku Pengguna Sabu-sabu di Bawah 1 gram (Studi Pada Wilayah Hukum Kepolisian Resor Kota Bandar Lampung)

Jurnal Penelitian Hukum DE JURE, ISSN 1410-5632 Vol. 18 No. 3, September 2018: 415 - 432 Implementasi Undnag-Undang Narkotika Ditinjau Dari Prespektif Hak Asasi Manusia (Implementation the Narcotics Laws Viewed from the Perspective of Human Rights)

Ulang Mangun Sosiawan, "Perspektif Restorative Justice Sebagai Wujud Perlindungan Anak Yang Berhadapan Dengan Hukum", Jurnal Penelitian Hukum DE JURE, Vol.16, No.4, Desember 2016.

Ali Johardi. (2021). Rumitnya Eksekusi Mati Terhadap Terpidana Mati Narkotika. Jurnal Hukum Sasana, 7(1). https://doi.org/10.31599/sasana.v7i1.486

Ali Johardi. (2021). Kompol Yuni Dalam Pusaran Kasus Penyalahgunaan Narkoba; Sebagai Pelaku Atau Korban?. KRTHA BHAYANGKARA, 15(1). https://doi.org/10.31599/krtha.v15i1.596

Amin, R. . (2020). Analisis Perlindungan Hukum Saksi Pelaku Yang Bekerjasama (Justice Collaborator) Perkara Tindak Pidana Narkotika Dalam Sistem Peradilan Pidana Di Indonesia. Jurnal Hukum Sasana, 6(2). https://doi.org/10.31599/sasana.v6i2.271

\section{Surat Kabar Online}

https://indonesiana.tempo.co/read/76811/2016/06/03/Kejahatan-Narkoba-diIndonesia:-Analisa-Hukum-Pidana

http://jabar.tribunnews.com/2016/06/18/revisi-uu-Narkotika-jangan-didikteberbegai-kebijakan-global

Bhakti Eko Nugroho, htpp://catatan-orang-biasa.blogspot.com/2008/12/benarkah penggunaan-drugs-adalah.html 
Available online at: http://ejurnal.ubharajaya.ac.id/index.php/sasana

A. Kadarmanta, Kejahatan narkotika: Extraordinary crime dan extraordinary punishment, http://kejahatan-narkotika-extraordinary-crime.html 